\title{
DISCUSSION ON THE TALENT TRAINING OF UNIVERSITIES WITH INDUSTRY CHARACTERISTICS FROM THE PERSPECTIVE OF COURSES
}

\author{
Xiaojie Geng ${ }^{1}$, Li Shen ${ }^{2}$, Yanxi Deng ${ }^{1}$ and $\mathrm{Li} \mathrm{Lin}^{1}$ \\ ${ }^{1}$ China university of Geosciences, Beijing, 100083, China \\ ${ }^{2}$ School of Remote Sensing and Information Engineering, \\ Wuhan University, Wuhan, China
}

\begin{abstract}
Geological colleges are important parts of industry characteristic colleges in China and national base for training geoscience talents. Intensify the liberal education at undergraduate level is of great significance for students to improve relevant cross-disciplinary study and further interdisciplinary research. Since the 21 st century, the attributes and scales of geological universities have changed greatly, and the demand and cultivation of innovative talents become urgent. Based on statistical data of China University of Geosciences (Beijing), we indicated the primary impacts of general knowledge on students' performance of diploma project. This study emphasized that to strengthen the liberal education, focus on applications, and explore training models for innovative talents are inevitable for industry colleges, in order to adapt to the rapid social development and industry demands.
\end{abstract}

\section{KEYWORDS}

liberal education; diploma project; talent training; geology

\section{INTRODUCTION}

The cultivation of innovative talents plays a vital role for national, industrial and corporate development. Industry-specific universities are an important part of China's higher education system and the main bases for training high-level talents. To improve the quality of higher education and cultivate innovative talents is not only the fundamental task of industry-specific universities, but also an important mission to build an innovative country [1]. Geology originated from the demand of human society for mineral resources such as petroleum, coal, metals, and non-metals. At present, the geological education in China has entered an unprecedented period of vigorous development in history. According to statistics, there were totally 176 geological schools nationwide by the year 2018 and geology graduates at various levels of colleges and universities reached about 120,000 in 2016 [2].

With the increasing demand for high-quality geological talents, various geological colleges and universities are exploring innovative talent training models. Curriculum system, practical teaching, student quality development, training needs and training platform constitute the basic elements of the talent training model [3], among which curriculum is the foundation and core of talent training. Some scholars have found through a comparative study of the training programs of multiple geological schools that in the training system of geological talents, general education courses and professional basic courses account for $50.10-66.80 \%$ of credits [4], which can be 
seen in general education. Class courses have an important position in the training process of geology majors (Table 1).

Table 1. Comparison table of geology major curriculum systems in domestic universities (Modified from reference [4])

\begin{tabular}{|c|c|c|c|c|c|}
\hline & & $\begin{array}{l}\text { China university of } \\
\text { Geosceinces } \\
\text { (Beijing) }\end{array}$ & $\begin{array}{c}\text { China } \\
\text { university of } \\
\text { Geosceinces } \\
\text { (Wuhan) }\end{array}$ & $\begin{array}{c}\text { Jilin } \\
\text { University }\end{array}$ & $\begin{array}{l}\text { Norehwest } \\
\text { University }\end{array}$ \\
\hline \multicolumn{2}{|c|}{ Hours } & $\begin{array}{l}2976 \text { hours } \\
+30 \text { weeks }\end{array}$ & $\begin{array}{c}2480 \text { hours } \\
+31.5 \text { weeks }\end{array}$ & $\begin{array}{l}2350 \text { hours } \\
+37 \text { weeks }\end{array}$ & $\begin{array}{l}3128 \text { hours } \\
+16 \text { weeks }\end{array}$ \\
\hline \multicolumn{2}{|c|}{ Credits } & 209.5 & 208.5 & 170 & 169 \\
\hline \multirow{2}{*}{$\begin{array}{l}\text { Required } \\
\text { Courses of } \\
\text { General } \\
\text { Education }\end{array}$} & $\begin{array}{l}\text { Hours / } \\
\text { Credits }\end{array}$ & $680 / 39$ & $808 / 50.5$ & $1272 / 67.5$ & $1530 / 68$ \\
\hline & $\begin{array}{l}\text { Percentage } \\
\text { of credits }\end{array}$ & $18.60 \%$ & $24.20 \%$ & $39.70 \%$ & $40.20 \%$ \\
\hline \multirow{2}{*}{$\begin{array}{l}\text { Disciplinary } \\
\text { Fundamental } \\
\text { Courses }\end{array}$} & $\begin{array}{l}\text { Hours / } \\
\text { Credits }\end{array}$ & $1368 / 85.5$ & $864 / 54$ & $672 / 42$ & $972 / 45$ \\
\hline & $\begin{array}{l}\text { Percentage } \\
\text { of credits }\end{array}$ & $40.80 \%$ & $25.90 \%$ & $24.80 \%$ & $26.60 \%$ \\
\hline \multirow{2}{*}{$\begin{array}{c}\text { Specialized } \\
\text { Core } \\
\text { Courses }\end{array}$} & $\begin{array}{l}\text { Hours / } \\
\text { Credits }\end{array}$ & $528 / 33$ & $528 / 33$ & $192 / 12$ & $410 / 21$ \\
\hline & $\begin{array}{l}\text { Percentage } \\
\text { of credits }\end{array}$ & $15.80 \%$ & $15.90 \%$ & $7 \%$ & $12.40 \%$ \\
\hline \multirow{2}{*}{$\begin{array}{l}\text { Selective } \\
\text { Courses }\end{array}$} & $\begin{array}{l}\text { Hours / } \\
\text { Credits }\end{array}$ & $256 / 16$ & $280 / 17.5$ & $214 / 13.5 \%$ & $216 / 14$ \\
\hline & $\begin{array}{l}\text { Percentage } \\
\text { of credits }\end{array}$ & $7.60 \%$ & $8.40 \%$ & $8 \%$ & $8.30 \%$ \\
\hline \multirow{2}{*}{$\begin{array}{l}\text { Practice } \\
\text { Courses }\end{array}$} & $\begin{array}{l}\text { Hours / } \\
\text { Credits }\end{array}$ & $\begin{array}{c}\text { 30weeks+144hours } \\
\text { /30 }\end{array}$ & 31.5 weeks/45.5 & $\begin{array}{c}37 \text { weeks/3 } \\
5\end{array}$ & 16weeks/21 \\
\hline & $\begin{array}{l}\text { Percentage } \\
\text { of credits }\end{array}$ & $14.30 \%$ & $21.80 \%$ & $20.50 \%$ & $12.50 \%$ \\
\hline
\end{tabular}

In the system engineering of talent training, diploma project is a key assessment between comprehensive application of undergraduate knowledge and the innovation ability. Through the graduation design, it can not only test comprehensive capability of students for four years' learning of basic and professional knowledge, exercise students' independent thinking and practical skills, strengthen their innovation consciousness and engineering concepts, and also cultivate students to develop meticulous and rigorous scientific attitudes, regulate students' academic behaviors. Moreover, the diploma project also provides a platform for students to display their learning achievements of professional quality and practice ability. Therefore, it can be applied to indirectly assess the undergraduate teaching. However, how are general courses affecting the performance of diploma project of undergraduates? Relevant researches are still lacking.

In this study, based on a wealth of statistics over the last decade in School of Earth Sciences and Resources, China University of Geosciences (Beijing), we implemented analysis on the correlation between general courses grades and diploma project performance. The objectives of this study were to (1) qualify the impact of general courses on diploma project of graduates, and (2) provide reasonable suggestions for the construction and development of innovative talent training mode. 


\section{DAta AND Methods}

\subsection{Data Set}

The general education curriculum scores of undergraduates during 2004-2015 were collected from the School of Earth Sciences and Resources of China University of Geosciences (Beijing), covering 5 majors including geochemistry, geology, resource exploration engineering (solid minerals)and tourism geology. Scores of diploma project and 16 general courses were selected, including College Physics, Advanced Mathematics, Physical Education, Linear Algebra, College Computer, Ethics and Fundamentals of Law, Principles of Marxism, Situation and Policies.

\subsection{Data Processing and Statistical Analysis}

The general courses were divided into six categories, i.e. physical education, foreign language, mathematics, physics, computer, and politics. We first convert the grades into a hundred-point system, where excellent equals to 90 points, good is 80 points, medium is 70 points, passing is 60 points, failure is 50 points, and 0 indicates no record. Then we used multiple regression to analyze the correlation between the scores of general courses and the diploma design, and determine the impact of general courses on the graduation design by the direction and strength of the linear relationship between the two variables.

SPSS is used to calculate the correlation coefficient of Pearson's product-moment, which expresses the influence of various course results on graduation design. The correlation coefficient can take any value between -1 and 1 . A positive correlation coefficient indicates a positive correlation between the two. For the output results of the correlation analysis, the significance level is less than 0.05 , which indicates that the correlation between the two data is significant.[5]. SPSS is used to perform multiple linear regression analysis. The multiple linear regression analysis in this article uses the graduation design grades as the dependent variable and various general education courses as independent variables to construct a regression equation to analyze the influence of various grades on the graduation design grades.

\section{RESUltS}

\subsection{Correlation between the Scores of General Courses and the Diploma Project}

Overall 3135 cases, it was found that each score of the six categories showed significant positive correlation with the performance of diploma project $(\mathrm{P}<0.01)$. Mathematics course scores showed the strongest correlation with diploma project $(\mathrm{r}=0.327)$, followed by physics scores $(\mathrm{r}=$ $0.288)$, politics $(r=0.272)$ and computer $(r=0.205)$. The sores of foreign language and physical education played relatively lower impacts on graduation design (Table 2 ).

Table 2. Correlation results between graduation design scores and general education courses

\begin{tabular}{|c|c|c|c|c|c|c|}
\hline & $\begin{array}{c}\text { physical } \\
\text { education }\end{array}$ & $\begin{array}{c}\text { foreign } \\
\text { language }\end{array}$ & mathematics, & physics & computer & politics \\
\hline Correlation & 0.189 & 0.104 & 0.327 & 0.288 & 0.205 & 0.272 \\
\hline Significance & 0.000 & 0.000 & 0.000 & 0.000 & 0.000 & 0.000 \\
\hline $\begin{array}{c}\text { Number of } \\
\text { cases }\end{array}$ & 3135 & 3135 & 3135 & 3135 & 3135 & 3135 \\
\hline
\end{tabular}


To make a better understanding of the relative contributions of specific courses to the final performance of diploma design, we further calculated the Pearson correlation coefficients between each of the courses within categories with the diploma design grades. All of the variables were found to be highly correlated with the score of diploma design (Table 3). Interestingly, we found the magnitude of relevance might also depends on the implement time of the course, i.e. the closer the course time is to the graduation, the stronger the correlations with graduation design score. Taking mathematics courses as an example, the order of the three courses implemented from early to late was 1st Advanced Mathematics (the first academic year), 2nd Advanced Mathematics (the first semester of the second academic year), and Linear Algebra (the second semester of the second academic year), and the correlation coefficients were $0.124<$ $0.218<0.319$. Similar patterns were also detected for courses within the other categories.

Table 3.Correlation between graduation design results and general education courses results

\begin{tabular}{|c|c|c|c|c|}
\hline Course types & Course names & $\begin{array}{l}\text { Pearson } \\
\text { correlation }\end{array}$ & Significance & $\begin{array}{c}\text { Number of } \\
\text { cases }\end{array}$ \\
\hline \multirow{4}{*}{$\begin{array}{l}\text { Physical } \\
\text { Education }\end{array}$} & Physical Education (1) & 0.079 & 0.000 & 3135 \\
\hline & Physical Education (2) & 0.089 & 0.000 & 3135 \\
\hline & Physical Education (3) & 0.164 & 0.000 & 3135 \\
\hline & Physical Education (4) & 0.205 & 0.000 & 3135 \\
\hline \multirow{2}{*}{$\begin{array}{l}\text { Foreign } \\
\text { Language }\end{array}$} & College English (1) & 0.064 & 0.000 & 3135 \\
\hline & College English (2) & 0.108 & 0.000 & 3135 \\
\hline \multirow{3}{*}{ Mathematics } & $\begin{array}{c}\text { Advanced } \\
\text { Mathematics (1) }\end{array}$ & 0.124 & 0.000 & 3135 \\
\hline & $\begin{array}{c}\text { Advanced } \\
\text { Mathematics (2) }\end{array}$ & 0.218 & 0.000 & 3135 \\
\hline & Linear Algebra & 0.319 & 0.000 & 3135 \\
\hline \multirow{2}{*}{ Physics } & College Physics (1) & 0.187 & 0.000 & 3135 \\
\hline & College Physics (2) & 0.307 & 0.000 & 3135 \\
\hline
\end{tabular}

\subsection{Analysis of Regression Characteristics between Grade Data}

\subsubsection{Impacts of courses scores on the performance of diploma project for each year.}

SPSS is used to perform multiple linear regression analysis. In the output result, $\mathrm{R}$ represents the correlation coefficient between variables, R2 represents the degree of influence of the independent variable on the dependent variable, adjusted $\mathrm{R} 2$ represents the fitting effect of the data with the model, and the degree of freedom is the model if the input variable is less than 0.05 , the linear regression equation is valid.

According to the year, the performance data of each year from 2004 to 2015 is analyzed by linear regression, and the results are shown in Table 4. The results show that the significance level of the regression analysis is less than 0.05, and the regression equation composed of the result coefficients is considered valid. By observing the results of multiple linear regression for each year, it can be seen that the number of regression equations with the largest coefficients of mathematics scores has reached half, while sports scores and foreign language scores only appear once or twice with low coefficients. Therefore, it can be concluded that mathematics scores have the greatest impact on graduation design scores, followed by physics scores and political scores, while foreign language scores and sports scores have little effect on graduation design scores. 
Table 4.Relevant parameters of regression equation every year

\begin{tabular}{|c|c|c|c|c|}
\hline Year & Variable & $\begin{array}{c}\text { Standardization } \\
\text { factor }\end{array}$ & $\mathrm{R}^{2}$ & Significance \\
\hline \multirow[t]{2}{*}{2004} & Mathematics & 0.328 & \multirow{2}{*}{0.216} & 0.001 \\
\hline & Physical Education & 0.232 & & 0.002 \\
\hline \multirow[t]{3}{*}{2005} & Mathematics & 0.254 & \multirow{3}{*}{0.287} & 0.003 \\
\hline & Politics & 0.188 & & 0.011 \\
\hline & Computer & 0.193 & & 0.026 \\
\hline \multirow[t]{2}{*}{2006} & foreign language & 0.271 & \multirow{2}{*}{0.174} & 0.000 \\
\hline & Physical Education & 0.254 & & 0.000 \\
\hline \multirow[t]{2}{*}{2007} & Mathematics & 0.218 & \multirow{2}{*}{0.160} & 0.007 \\
\hline & Physics & 0.213 & & 0.008 \\
\hline \multirow[t]{2}{*}{2008} & Mathematics & 0.376 & \multirow{2}{*}{0.211} & 0.000 \\
\hline & Politics & 0.152 & & 0.009 \\
\hline \multirow[t]{2}{*}{2009} & Politics & 0.280 & \multirow{2}{*}{0.214} & 0.000 \\
\hline & Mathematics & 0.275 & & 0.000 \\
\hline 2010 & Politics & 0.400 & 0.160 & 0.000 \\
\hline \multirow[t]{2}{*}{2011} & Politics & 0.207 & \multirow{2}{*}{0.088} & 0.001 \\
\hline & Mathematics & 0.144 & & 0.015 \\
\hline \multirow[t]{2}{*}{2012} & Mathematics & 0.278 & \multirow{2}{*}{0.149} & 0.000 \\
\hline & foreign language & 0.165 & & 0.008 \\
\hline \multirow[t]{2}{*}{2013} & Physics & 0.243 & \multirow{2}{*}{0.138} & 0.000 \\
\hline & Politics & 0.195 & & 0.001 \\
\hline 2014 & Mathematics & 0.424 & 0.180 & 0.000 \\
\hline \multirow{3}{*}{2015} & Computer & 0.209 & \multirow{3}{*}{0.258} & 0.007 \\
\hline & Politics & 0.203 & & 0.001 \\
\hline & Mathematics & 0.233 & & 0.002 \\
\hline
\end{tabular}

\subsubsection{Linear regression characteristics of global data}

This study not only performed regression analysis on the data of each year, but also performed multiple linear regression analysis according to all the data to obtain the linear regression influence of the global data, as shown in Table 5. It can be seen from the table that the significance level of the coefficients of each variable and the significance level of the model are still less than 0.05 , indicating that the regression equation established by the variable coefficients is more effective. All kinds of general education achievements have a positive influence on graduation design achievements. According to the results of the regression equation coefficients, the coefficient of mathematics performance is the largest among all independent variables. That is to say, mathematics performance has the greatest impact on graduation design performance, followed by physical performance and political performance. The impact of graduation design results is relatively small. From the vertical comparison of the years and the horizontal comparison of the courses and subjects, it can be shown that the mathematics score has a significant impact on the graduation design of our school's geological students.

Table 5.Global data regression results

\begin{tabular}{|c|c|c|c|c|}
\hline Variable & Standardization factor & Significance & \multirow{2}{*}{$\mathrm{R}^{2}$} & Model significance \\
\hline Mathematics & 0.194 & 0.000 & & \\
\cline { 1 - 3 } Physics & 0.149 & 0.000 & \multirow{3}{*}{0.147} & \multirow{2}{*}{0.000} \\
\hline Politics & 0.091 & 0.000 & & \\
\hline Physical Education & 0.064 & 0.000 & & \\
\hline Foreign language & 0.049 & 0.004 & & \\
\hline
\end{tabular}




\section{DISCUSSION}

\subsection{To Establish a Cross-Training Model that Strengthens Foundation and Multi- Disciplinary Penetration.}

Curriculum is the basis for talents training. Due to the complexity of geology processes, involving a variety of physical and chemical processes, the geology is also a multidisciplinary science, which is restricted by other basic disciplines such as mathematics, physics and chemistry [6]. In order to cultivate more first-class geologists, it is of great necessity to consolidate the foundation of the basic disciplines, especially mathematics, physics and chemistry and biology [7]. In the process of training undergraduates majoring in geology, it is not only important to strengthen their foundation of learning general courses, but also necessary to highlight the implication of broadening orientation, emphasis practical application, as well the implement of a cross-disciplinary mode in training outstanding persons [4]. In the process of carrying out education reform, colleges and universities should increase the proportion of general courses in education and teaching, incorporate them into the professional curriculum system, in order to lay a solid foundation for students to develop interdisciplinary researches.

\subsection{The Development of Geology Puts Forward New Requirements for the Training of Geoscience Talents}

Talent training mode and curriculum system are closely related to the needs of times and national development. In the 1950s, it was in urgent need of mineral resources and energy resources for the economic development of China, thus proposed the guidance principle of geological work to be centered on prospecting [8]. In terms of the system and goals of geological education, to cultivate in prospecting specialists were overemphasized. However, with the rapid development of social economy, the field of geology has been largely broadened, and lots of new marginal and interdisciplinary subjects have formed. The research fields and employment directions of geology are also expanding. All these have put forward new requirements for the cultivation of talents, and also become a challenge for the sustainable development of geological colleges and universities. Some scholars have proposed that the intersection of different disciplines could provide energy for the development of superior disciplines, promote the growth of emerging disciplines, lead the way for major innovations and breakthroughs, and provide opportunity for the commanding heights of talent training [9]. Taking the geology science base class in China University of Geosciences (Beijing) as an example, the goal of setting such classes was to cultivate high-level geoscience talents with global, modern and long-term perspectives, high scientific quality, strong scientific innovation ability and broad knowledge. After years of practice and exploration, a curriculum system that strengthens the foundation and practice has been constructed, and a systematic project for the training of geoscience talents has been formed.

\subsection{To Explore the Talent Training Mode and Evaluation System with Geoscience Characteristics.}

The cultivation of undergraduates is a systematic project. The talent training mode mainly includes course management system, social practice system, diploma project system, employment training system, etc. [10]. Diploma project is the final but the most comprehensive and important examination of the teaching and learning achievements for undergraduates. It plays an important role in the inspection of the basic knowledge, professional knowledge and engineering ability of the students [11]. However, diploma project is not the only criterion for evaluating the effect of undergraduate talent training. It is also somewhat one-sided to study the impact of basic general courses on diploma project performance. As the talent supply side, colleges and universities not 
only control the management, allocation, and decision-making power of education resources, but also determine formation of human character and integrated quality.

In summary, from the perspective of geological colleges and universities, we should focus on the quality characteristics of innovative talents in colleges and universities, combined with industry needs, clarify the rules and characteristics of special professional talent training, and establishing innovative talent training models and talent training evaluation index systems.

\section{Conclusions}

Based on the analysis of the results of graduates majoring in geology at China University of Geosciences (Beijing), this paper concludes that there is a positive correlation between general courses and the quality of diploma project, and mathematics performance has the greatest impact on graduation design performance. In the process of carrying out education reform, colleges and universities should increase the proportion of general courses in education and teaching, incorporate them into the professional curriculum system, in order to lay a solid foundation for students to develop interdisciplinary researches. In the process of training undergraduates majoring in geology, it is not only important to strengthen their foundation of learning general courses, but also necessary to highlight the implication of broadening orientation, emphasis practical application, as well the implement of a cross-disciplinary mode in training outstanding persons

\section{ACKNOWLEDGEMENTS}

This work was supported by the National Scientific Funding Project (72041020). Authors are thankful to two anonymous referees for providing useful and fair review.

\section{REFERENCES}

[1] Yao Kai, Li Shizhi, Wang Jiaojiao, (2020)Research on Cultivation Mode for Entrepreneurial Talents in Colleges and Universities, Modern Education Management, Vol. 4, pp40-46.

[2] Yu Jicong, Liu Yuexiang, Zhao Weizhen, (2018) Reflections on the Development of Geological Education in the New Era, Chinese geological education, Vol. 4, pp 1-5.

[3] Yuan Xingguo. (2011). The Exploration and Analysis of Reforming Talent Cultivating Modelin Application-oriented Institutes, Energy Procedia, Vol. 5, pp 2092-2096.

[4] Qu xiyu \& QiuLongwei, (2018), Disscussion on Undergraduates Training Model of Geology in the College, Education teaching forum, Vol.27, pp 80-83.

[5] JamesE.Burt, GeraldM.barber, DavidL. Rigby. Elementary Statistics for Geographers Third Edition[M]. USA :The Guilford Press, 2009.

[6] Bi Kongzhang \& Hu Xuankui, (2002), Thoughts and Suggestions on Earth Science Education, Chinese geological education, Vol. 20, pp 58-60.

[7] Wang Xunlian, Cen Kuang, Hu Ling, (2004), Exploration and Practice of Innovative Cultivation Model of Geoscience Talents, Chinese geological education, Vol.4, pp29-33.

[8] Dong Fuxiang\& Liu Li. (2010), The scientific model of geology curriculum system in the 21st century, Journal of Jilin Radio and TV University,Vol.9, pp5-8. 
International Journal of Education (IJE) Vol.8, No.3, September 2020

[9] Lu Yongxiang. (2005), The meaning of interdisciplinary and interdisciplinary, Bulletin of the Chinese Academy of Sciences, Vol. 20, pp 58-60.

[10] Chen Wenmin, Wu Cuihua, Yu Jiangpeng, (2015), Analysis of System Elements of Innovative Talents Training Mode, Road to success, Vol.26, pp3-4.

[11] Yang Shuyu, Cheng Li, Pan Surong, (2020), Reform and Practice of the Graduate Project under the Background of Engineering Education Major Certification, Education Teaching Forum, Vol. 5, pp 187-188.

\section{AUTHORS}

XiaojieGeng, earned her Ph.D. in Geology in 2015 from China university of Geosciences, Beijing. She worked in the academicaffairs office as a manage for more than three years. Her research focus on higher education. 